NBER WORKING PAPER SERIES

\title{
PORTFOLIO CHOICE AND \\ HEALTH STATUS
}

\author{
Harvey S. Rosen \\ Stephen $\mathrm{Wu}$ \\ Working Paper 9453 \\ http://www.nber.org/papers/w9453
}

\author{
NATIONAL BUREAU OF ECONOMIC RESEARCH \\ 1050 Massachusetts Avenue \\ Cambridge, MA 02138 \\ January 2003
}

We are grateful to Princeton's Center for Economic Policy Studies for financial support and to Bo Honoré, Burt Malkiel, Jonathan Meer, Ann Owen, James Poterba, Kent Smetters, an anonymous referee, and participants in seminars at Brigham Young, Northwestern, and Princeton Universities for useful suggestions. The views expressed herein are those of the authors and not necessarily those of the National Bureau of Economic Research.

C2003 by Harvey S. Rosen and Stephen Wu. All rights reserved. Short sections of text not to exceed two paragraphs, may be quoted without explicit permission provided that full credit including notice, is given to the source. 
Portfolio Choice and Health Status

Harvey S. Rosen and Stephen Wu

NBER Working Paper No. 9453

January 2003

JEL No. G11, I19

\section{ABSTRACT}

This paper analyzes the role that health status plays in household portfolio decisions using data from the Health and Retirement Study. The results indicate that health is a significant predictor of both the probability of owning different types of financial assets and the share of financial wealth held in each asset category. Households in poor health are less likely to hold risky financial assets, other things (including the level of total wealth) being the same. Poor health is associated with a smaller share of financial wealth held in risky assets and a larger share in safe assets. We find no evidence that the relationship between health status and portfolio allocation is driven by "third variables" that simultaneously affect health and financial decisions. Further, the relationship between

health status and portfolio choice does not appear to operate through the effect of poor health on individuals' attitudes toward risk, their planning horizons, or their health insurance status.

Harvey S. Rosen

Department of Economics

Princeton University

Princeton, NJ 08544

and NBER

hsr@princeton.edu
Stephen Wu

Department of Economics

Hamilton College

Clinton, NY 13323

swu@hamilton.edu 


\section{Introduction}

Economists have long realized the importance of understanding individual portfolio choice. Recent empirical work on individual portfolio choice has focused on a number of important questions, including the impacts of bequest motives (Hurd [2002]), undiversifiable human capital risk (Heaton and Lucas [2000]), and the differential tax treatment of income generated by various assets (Poterba [2001]).

The role of health status has received little attention. While several studies have documented that health affects total wealth accumulation (Smith [1999], Venti and Wise [2000], Wu [2003]), there is much less research on how health influences the allocation of that wealth to various assets. Edwards [2002] develops a theoretical model in which health risk determines portfolio shares through its effect on risk aversion. One can imagine other channels through which health could affect portfolio composition. Poor health may influence an individual's marginal utility of consumption, her degree of risk aversion, rate of time preference, and the variability of her labor income, all of which could affect portfolio composition. Because health tends to deteriorate with age and older people control a disproportionate amount of total wealth, it seems particularly pressing to understand how poor health affects portfolio allocation decisions.

The purpose of this paper is to investigate whether differences in health status help explain differences in individual portfolio composition, ceteris paribus. We examine how health status is related to both the probability that a household holds a particular type of asset in its portfolio, and the share of financial wealth held in each asset category. The remainder of the paper is organized as follows. Section 2 reviews previous empirical work on household portfolio choice. Section 3 discusses the empirical 
strategy and describes the data. In Sections 4 and 5 we examine the impact of health status on the choice of assets and on the proportion of financial wealth held in the various assets, respectively. We find that health effects are present in both sets of decisions. In particular, households in poor health are less likely to hold all classes of financial assets, other things (including the level of total wealth) being the same. Further, poor health is associated with a larger share of financial wealth held in safe assets and a smaller share in other classes of assets. Section 6 concludes with a summary and suggestions for future research.

\section{Previous Literature}

A rich theoretical literature demonstrates how portfolio decisions depend on factors such as risk aversion and investment opportunities. ${ }^{1}$ Early contributions analyzed static models in which an investor selects the portfolio that maximizes expected utility given total wealth and the risk-return pattern of available assets (Tobin [1958] and Mossin [1969]). More recent research has moved to a dynamic framework in which one's portfolio is selected to maximize expected lifetime utility. Important issues include the role of incomplete portfolios (King and Leape [1998]), human capital uncertainty (Heaton and Lucas [1997]), the ability to substitute labor income for asset income (Bodie, Merton and Samuelson [1992]), and uncertain time horizons (Foldes [2000]).

The empirical literature on portfolio choice has sought to find observable variables that explain cross sectional variation in portfolio behavior. Typically, the covariates used include resources available to the household (total wealth and income) as well as demographic characteristics (age, race, gender, marital status). Such variables are 
generally statistically significant and quantitatively important in regressions explaining portfolio behavior, both in U.S. and European data. (See, for example, Bertaut and StarrMcCluer [2002], Carroll [2001] and Guiso et al. [2002]).

Most empirical work in this area addresses two distinct but related questions regarding portfolio choice. First, does the individual or household hold a positive amount of a given asset at all? Second, what proportion of the total portfolio is held in each asset? This approach of estimating reduced-form models for ownership probabilities and for portfolio shares has served as a fruitful starting point for analyzing a number of issues relating to portfolio allocation. Examples include Poterba and Samwick [1999], who include marginal tax rates to study the impact of the federal income tax; Heaton and Lucas [2000], who use a measure of the variability of labor income to investigate whether the riskiness of human capital affects the demand for financial assets; and Edwards [2002], who includes an attitudinal variable--the individual's subjective probability that health will limit her work activity over the next decade--to examine whether health risk affects portfolio choice. We adopt the same basic approach to analyze the effect of health status on portfolio composition.

\section{Data and Empirical Strategy}

\subsection{Description}

We use data from four waves of the Health and Retirement Study (HRS). The HRS is a nationally representative panel that follows across time approximately 7,000 households with a primary respondent between the ages of 51 and 61 during the first year of the survey. The first wave of the study was conducted in 1992, so the primary respondents

\footnotetext{
${ }^{1}$ See Gollier [2002] for an excellent survey.
} 
represent cohorts born between 1931-1941. The next three waves of the survey were collected in 1994, 1996, and 1998. While this sample is clearly not representative of the entire age distribution of households, Poterba [1994, p. 2] and others have shown that net worth is highly concentrated among older households. Further, tabulations from the 1998 Survey of Consumer Finances indicate that households headed by individuals between the ages of 51 and 67 own about 44 percent of the equity in the economy. Hence, as suggested above, this is an important group to study in the context of portfolio composition issues.

The survey includes detailed information on health and cognitive status, and a variety of economic and demographic variables. Of particular interest for our analysis is that the HRS provides information on each household's holdings of a quite comprehensive set of financial assets: checking, savings and money market accounts, CDs, bonds and bond funds, government savings bonds and T-bills, stocks, mutual funds and IRA and Keogh accounts.

Conducting an analysis of portfolio decisions requires that one specify the set of assets from which the investor chooses. In practice, some arbitrariness is involved in aggregating financial assets into relatively homogeneous groups that are suitable for statistical analysis. A typical strategy is to collapse financial assets into three classes, "safe," "medium risky," and "risky" (Hurd [2002]), although some studies construct as many as eight to ten categories (Poterba and Samwick [1999]). We use a four-way classification scheme consisting of safe assets (checking and savings accounts, money market funds, CDs, government savings bonds and T-bills), bonds (corporate, municipal and foreign bonds and bond funds), risky assets (stocks and mutual funds), and retirement 
accounts (IRAs and Keoghs). This is quite similar to Hurd's [2002] approach, except that he combines retirement accounts and bonds into one category. However, given the special tax treatment of IRA and Keogh accounts, and the fact that they may be relatively illiquid for some households, it seems sensible to segregate them (as do Poterba and Samwick [1999] and King and Leape [1998]). Unfortunately, the HRS does not indicate what kinds of assets are in the retirement accounts. The Survey of Consumer Finances (SCF) does provide some information. On the basis of SCF tabulations, we allocated each household's retirement accounts to stocks and bonds. Doing so did not change the substantive results of our analysis of portfolio shares. ${ }^{2}$

Table 1 presents summary statistics of the key variables, including demographic characteristics and financial wealth holdings. The average age (over the four-year panel) of husbands is roughly 60 years and the average age of wives is 56, while singles are 59 years of age on average. 58 percent of single people are female and 18 percent are black. For married couples ${ }^{3}$, approximately 6 percent of husbands and wives are black. Single people have slightly over $\$ 38,000$ in financial assets on average; the figure for couples is about $\$ 95,000$.

Approximately 67 percent of singles and 80 percent of married couples have a positive amount of safe asset holdings. It is not quite clear how to interpret this figure, particularly because virtually everyone in this sample presumably has Social Security wealth, which is generally perceived to be a "safe" asset. Hence, we do not include safe assets in our discussion of ownership probabilities in Section 4. The percentages for the other categories are much lower - only 20 percent of singles own any risky assets, while

\footnotetext{
${ }^{2}$ We thank Andrew Samwick for providing us with the relevant SCF data.
} 
33 percent of married couples have a positive amount of these assets. The analogous numbers for bonds are only 4 percent and 7 percent. The figures in this table are consistent with previous findings that many households have incomplete portfolios in the sense that they do not own positive amounts of every type of asset. Conditional on having financial wealth, the great majority of it is held in safe assets - an average of 64 percent for singles and 54 percent for couples. ${ }^{4}$

One important issue in studying portfolio shares is how broadly the measure of wealth in the denominator should be defined. Different pictures can emerge if one uses financial assets, all physical assets (including homes and automobiles), or physical assets plus human capital as the relevant measure of wealth (Heaton and Lucas [2000]). We follow most previous investigators in looking at shares of financial assets. We compute portfolio shares for all individuals who report positive financial assets. ${ }^{5}$

Our health status variable is based on the answer to the following question: "Would you say your health in general is excellent, very good, good, fair, or poor?" The HRS codes the answers to this question on a 1 to 5 scale, with 1 representing excellent health and 5 representing poor health. We create a dichotomous variable Sick, which takes a value of one if the individual rates his or her health as "fair" or "poor" and zero otherwise. $^{6}$ A large literature documents the validity of self-reported health measures. Poor self-reported health is strongly correlated with mortality even after controlling for

\footnotetext{
${ }^{3}$ There are a few non-married cohabiters whom we include in this category. Excluding these households has no effect on our results.

${ }^{4}$ The finding that a substantial number of U.S. households have no safe assets--or no financial assets whatsoever--has been documented in a number of data sets. See, for example, Bertaut and Starr-McCluer's [2002, p. 190] tabulations from the Survey of Consumer Finances (SCF). When a household reports not having even a checking account, the SCF asks why. Typically, such households reply that the fees are too high, they do not write enough checks to make it worthwhile, and so on.

${ }^{5}$ Some researchers exclude households whose financial net worth does not exceed some threshold (Heaton and Lucas [2000]).
} 
indices of functional capacity, the presence of specific medical conditions and physician health assessments (Idler and Benyamini [1997]). ${ }^{7}$ Additional evidence along these lines is provided by Hurd and McGarry [1995], who find correlations in the AHEAD data between self-reported health status and both mortality and the onset of several serious health conditions, after controlling for various socio-demographic conditions. ${ }^{8}$ That said, in the psychology literature some have argued that an individual's subjective health evaluations may be distorted by his or her mood (Schmidt et al. [1996]). We therefore also estimated our model using several alternative measures of health status, including specific medical conditions and an index of the individual's ability to conduct activities of daily living. The results were qualitatively similar to those using self-reported health status.

\subsection{Some Cross Tabulations}

We begin our exploration of the relationship between health and portfolio decisions by showing how the proportion of households owning various assets and their respective portfolio shares vary with health status (Table 2). Results are shown separately for single and married people. For both individuals and couples, being healthy increases the probability of owning each one of the financial assets. For example, 25.1 percent of healthy single people own some risky assets; for sick single people the analogous number is only 8.2 percent. Similarly, 38.5 percent of couples in which both

\footnotetext{
${ }_{7}^{6}$ Analysis using all five indicator variables does not change our substantive results.

${ }^{7}$ An alternative approach suggested by Edwards [2002] is to focus on the individual's expectation that, over a period of time such as a decade, her health will interfere with her ability to work. However, this limits the sample since the variable is defined only for individuals who are in the labor force at the time the question is asked.

${ }^{8}$ As an alternative way to investigate this issue, we included an indicator for the individual's mental health status as a covariate in our basic model. If mental health is driving both self-reported health status and financial decisions, then inclusion of mental health should reduce the impact of self-reported health status. However, such does not appear to be the case in our data.
} 
spouses are healthy own some risky assets; the figure is only 12.2 percent for couples in which both spouses are sick. The right hand side of Table 2 indicates that health status is also correlated with the proportion of financial wealth held in each asset category. Married couples with two healthy spouses hold an average of 49.5 percent of their financial wealth in safe assets and 18.9 percent in risky assets, while couples with both spouses who are sick hold 74.7 percent in safe assets and only 6.6 percent in risky assets. A similar relationship between health status and portfolio shares holds for singles.

Although Table 2 indicates that differences in health status are associated with differences in ownership probabilities and portfolio shares, a number of variables are known to be correlated with health status and some of these could also be correlated with portfolio decisions. Hence, while these results are suggestive, we now turn to a multivariate approach. We discuss ownership probabilities and portfolio shares in Sections 4 and 5, respectively.

\section{Ownership Probabilities}

\subsection{Estimation Issues}

Our goal is to determine whether variations in health status exert an independent effect on the probability that a household owns each of the four types of assets. We follow the general strategy employed in previous papers and estimate a probit model for the probability of owning each asset, including on the right hand side our dichotomous variable for poor health and controls for total wealth, ${ }^{9}$ income and other demographic characteristics. We pool together the data from the four waves of the HRS

\footnotetext{
${ }^{9}$ Total wealth includes the value of all net housing equity, all vehicles, net business equity, financial assets, and other assets including real estate. It does not include pension or social security wealth. However,
} 
and use a random effects estimator of the parameters. ${ }^{10} \mathrm{We}$ also include a year effect for each wave.

Two major issues must be addressed in estimating these models. The first is how to treat married couples versus singles. The typical practice of simply including an indicator variable for marital status (for example, Bertaut and Starr-McCluer [2002]) is really not suitable in our context. There are potentially interesting questions about decision making within households that are best explored if separate equations are estimated for single and married individuals. ${ }^{11}$ This decision is reinforced by Barber and Odean's [2001] finding that married and single people follow different stock trading strategies; their other portfolio decisions might differ as well.

The second issue relates to the treatment of health status for married couples. Because of different life expectancies, husbands and wives may have different time horizons. Further, there is some evidence that men and women differ with respect to risk aversion (Barber and Odean [2001] and Lott and Kenny [1999]). These considerations suggest that men and women may favor different portfolio strategies, and that the impact on the family's portfolio when one or the other is ill may differ. Hence, there is no reason to expect health effects for the two spouses to be symmetric, so an average or combined measure is inappropriate. Instead, we enter one indicator variable for the husband's health status, and another for the wife's. ${ }^{12}$

when the wealth variable is augmented with an imputation for pension wealth, none of the substantive results changes.

${ }^{10}$ With a random effects estimator, identification of the health status coefficients comes in part from changes in health status within households over time.

${ }^{11}$ Browning [2000] and Mazzocco [2002] provide discussions of savings behavior in households with more than one decision maker.

${ }^{12}$ As noted below, we also allowed for the possibility of an interaction between the spouses' health outcomes and found that, in general, it had no impact on the substantive results. 
With respect to other covariates, our choices are quite conventional. We include age because risk aversion and the time horizon vary with it (Bertaut and Starr-McCluer [2002, p. 199]). ${ }^{13}$ Previous studies have indicated that education exerts an important influence on portfolio choice; in general, households with more education are more likely to hold diversified portfolios, perhaps because they have better information about various investment opportunities (King and Leape [1998, p. 190]). We include a set of dichotomous variables for educational attainment. We also include indicator variables for sex (in the equation for singles) and race, and the presence of any children, all of which could affect risk aversion, the decision-making time horizon and bequest motives. Theory suggests that the level of total wealth is an important determinant of portfolio allocation both because it can influence risk aversion and because there may be fixed costs to owning certain assets (Hurd [2002, p. 467]). To allow for nonlinearities in the impact of wealth, we enter it as a quadratic. Our wealth variable includes financial wealth in addition to physical capital such as net equity in housing and businesses. Following the tack suggested by some earlier studies, we experimented with a wealth variable that also included an estimate of individuals' human capital. ${ }^{14}$ This modification of the wealth variable had no impact on the estimates of health effects that are reported below. Finally, previous research has also shown that income is a significant determinant

\footnotetext{
${ }^{13}$ There is a well-documented negative correlation between health status and age. This raises the possibility that the failure to include health status in analyses of portfolio choice may bias estimates of age effects. However, when we estimated our models without health, the coefficients on the age variables generally did not change substantially.

${ }^{14}$ We follow Heaton and Lucas's [2000] algorithm for estimating human capital: Assume that for individuals under the age of 65, real labor income remains constant at its current level until age 65 and then ceases. For individuals over 65 who report labor income, assume that this income remains constant until age 70 and then ceases. Streams of labor income are discounted back to the respondent's current age at a real interest rate of 5 percent.
} 
of portfolio composition even conditional on wealth (King and Leape [1998]), and we also enter it as a quadratic. ${ }^{15}$

\subsection{Basic Results}

The probit estimates for single individuals and couples are reported in Tables $3 \mathrm{a}$ and $3 b$, respectively. The first column for each asset category gives the results for the basic specification. The second column for each category adds controls for parents' education and industry and occupation. ${ }^{16}$

Consider first the health effects for the single individuals in Table 3a. The results are quite striking. Being in poor health exerts a negative and statistically significant effect on the probability of owning each financial asset. ${ }^{17}$ Further, calculating the marginal effects from the probit coefficients listed in the table ${ }^{18}$, we find that the effects are quantitatively important. Specifically, the figures in the first columns under each of the assets imply that being in ill health reduces the probabilities of owning retirement accounts, bonds, and risky assets by $2.1,0.2$, and 1.7 percentage points, respectively. In short, the basic message from the cross tabulations in Table 2 continues to hold when we include other covariates: health affects asset choice.

An important question is whether the observed relationship between health and portfolio choice is somehow spurious. One way this might occur is if there is reverse causality - portfolio composition affects health rather than vice versa. We find this scenario implausible. Although the notion that there are dual pathways relating health

\footnotetext{
${ }^{15}$ The results are essentially unchanged when we use step functions for wealth and household income.

16 There are 12 industry categories and 17 occupations, based on standard census classifications.

${ }^{17}$ This is similar to Edwards' [2002] result that poor health reduces the likelihood of stock ownership. Edwards estimates his model treating the HRS waves as a series of independent cross sections.
} 
status and wealth is taken seriously in the literature (Smith [1999]), we can think of no compelling reason to believe that the allocation of that wealth to various assets would influence health status after controlling for the level of total wealth.

Another possibility is that some third variable drives both health status and portfolio choice. This seems a more substantial issue. Suppose, for example, that people with privileged family backgrounds learn more as children about the financial world and also acquire good health habits. In this case, the strength of the relationship between poor health and portfolio choice would be overestimated. Or perhaps certain jobs have more volatile income streams than others and at the same time involve more stress and worse working conditions than other jobs. Again, our estimated relationship between health status and portfolio choice would be biased. The HRS data provide us with some information that can be used to explore these possibilities. Although there is not extensive information on family background, we do know the parents' education. Further, household members' occupation and industry are reported. The second columns for each asset category in Tables $3 \mathrm{a}$ and $3 \mathrm{~b}$ show the results when the basic equations are augmented with parents' education and a set of industry and occupation dichotomous variables. Although there are some systematic relationships among occupation, industry and portfolio decisions (results not shown here), the magnitude and the significance of the health effects do not change substantially. Thus, to the extent that our data allow us to explore the possible influence of third variables, we find that they do not undermine our basic finding that health status affects asset choice.

Consider next the married couples in Table 3b. There are two health coefficients for each family, one each for the husband and the wife. As in Table 3a, the first column

\footnotetext{
${ }^{18}$ See Maddala [1983, p. 23].
} 
for each asset does not include controls for family background and occupational history, while the second column for each asset does. For virtually every asset type, the coefficient on poor health (of either spouse) is negative. The coefficients in the first columns of Table $3 \mathrm{~b}$ imply that poor health of a husband reduces the likelihood of owning retirement accounts and risky assets by 8.9 and 3.0 percentage points, respectively, and has essentially no effect on the probability of owning bonds. For wives, poor health decreases the likelihood of owning retirement accounts, bonds and risky assets by $6.5,0.2$, and 4.0 percentage points. Thus, just as for singles, poor health reduces the probability of owning each financial asset, ceteris paribus. Once again, including additional controls for parents' education, industry and occupation does not alter substantially the magnitude or significance of the health effects.

Computations based on the coefficients in Table $3 \mathrm{~b}$ suggest that a couple in which both spouses are in poor health is 7 percentage points less likely to hold risky assets than a couple in which both spouses are in good health, other things being the same. A natural question in this context is whether the cumulative impact when both spouses are ill is different from the sum of the individual effects. To investigate this issue, we augment each equation with an interaction between the husband's and wife's health variables. It turns out that these interactions are not significant for any of the assets (results not shown here), so that the joint effect when both spouses are in poor health is approximately equal to the sum of the individual spouses' effects.

We now discuss very briefly the coefficients on the other variables in Tables $3 \mathrm{a}$ and $3 \mathrm{~b}$. The findings are broadly consistent with those from previous studies. For example, the probability of owning each asset tends to increase with wealth and income; 
the probability of owning each asset increases with age; the probability of owning risky assets increases substantially with education; and blacks are much less likely to own risky assets than non-blacks. Single females are less likely to hold risky assets and retirement funds than single males, though there are no significant gender differences for the other assets. In results not reported here, we allow the health effects of singles to vary by gender by including an interaction between sex and health status. However, this interaction term is not significant for any of the assets.

\subsection{Mechanisms for Health Effects}

Taken together, Tables $3 \mathrm{a}$ and $3 \mathrm{~b}$ indicate that health status exerts important effects on portfolio choice. For both single and married households, poor health is associated with a lower probability of owning each financial asset. As noted in the introduction, there are various mechanisms through which health might affect portfolio choice. In this section we examine several of these mechanisms.

\subsubsection{Risk aversion}

As already noted, theory suggests that an investor's risk aversion is an important determinant of portfolio allocation. Respondents who become sick may become less (or possibly more) risk averse than previously. The HRS asks respondents a question that is designed to provide information about their attitudes toward risk--whether they would take a job that would double their income with a 50 percent chance and cut it in half with a 50 percent chance. To investigate whether health effects might operate through impacts on risk aversion, we define the dichotomous variable risk taker, which takes the value of one if the individual answers affirmatively to the question, and zero otherwise. The results when we augment our basic model with this variable are in the first panels of 
Tables $4 \mathrm{a}$ and $4 \mathrm{~b}$. (This question is asked only in the first wave of the survey, so only data from that year are used to estimate this variant of the model. The same applies to the questions relating to planning horizon and bequest motives discussed below.) The results indicate that more risk loving individuals are more likely to have risky assets (although not all the point estimates are statistically significant). While this finding is perfectly intuitive, including this self-reported risk aversion measure does not affect the estimated health coefficients substantially, for either singles or married couples. ${ }^{19}$ Hence, health does not appear to affect portfolio choices by affecting attitudes toward risk.

\subsubsection{Planning horizon}

The HRS asks, "In deciding how much of their (family) income to spend or save, people are likely to think about different financial planning periods. In planning your (family's) saving and spending, which of the time periods listed ...is most important to you [and your (husband/wife...)]?" The possible responses are: "next few months," "next year," "next few years," "next 5-10 years," and "more than 10 years." We create the dichotomous variable planl which takes a value of one if the first response was given and zero otherwise, plan 2 if the second response was given, and so on. If poor health affects portfolio choices by changing people's time horizons, then when we include these dichotomous variables, the health coefficient should become less important. The second panels of Tables $4 \mathrm{a}$ and $4 \mathrm{~b}$ show the results when we augment the original specifications with the plan variables. The results indicate that households with longer time horizons are more likely to have some of each type of asset, although the relationship is not

\footnotetext{
${ }^{19}$ Because these models are estimated using only the first year of the panel, the results are not directly comparable to those in Table 3a. Our assessment that the health coefficients do not change much is based on a comparison to the canonical model estimated using only the first wave, which is not reported here to conserve space.
} 
monotonic. However, including these variables in the model does not materially affect the health coefficients. Thus, there is little evidence that the results are driven by the fact that some households are more forward-looking than others.

The notion that planning horizons might be related to health raises the issue of life expectancy. The portfolios of unhealthy and healthy people may differ because unhealthy people do not expect to live as long. The HRS asks respondents to rate their chances of living to the age of 85 on a scale of one to ten. In results not reported here, we included this variable in our basic models, and found that one's perceived chance of living to 85 is not strongly related to asset allocation. Further, the health effects are about the same as in the basic model. ${ }^{20}$

\subsubsection{Bequest Motives}

In the same spirit, if an individual has a bequest motive, this may, in effect, extend his time horizon. The HRS asks individuals whether they intend to leave a sizable bequest to their heirs. The five possible answers to this question are "definitely", "probably", "possibly", "probably not" and "definitely not". We create a set of dichotomous variables on the basis of the responses and include it in the model. As indicated in the fourth panels of Tables $4 \mathrm{a}$ and $4 \mathrm{~b}$, the strength of the bequest motive is significantly related to the probability of ownership of financial assets, but it has no substantive impact on the coefficients on the health variables.

\footnotetext{
${ }^{20}$ A person's subjective probability of living a long time may depend on how optimistic he or she is. This raises another possibility--our results are driven by the fact that optimistic people buy risky assets and say they feel healthy. The HRS does ask respondents some questions that indirectly relate to their degree of optimism. In particular, the individuals were asked to rate the likelihood that the following would occur during the remainder of their lifetimes: double-digit inflation, major depression, Social Security becoming less generous, and housing prices rising faster than inflation.. These variables had no impact on portfolio
} 


\subsubsection{Health Insurance}

Another possibility is that bad health leads to large medical expenses, which induce changes in the portfolio. If this were the case, we would expect the impact of health to depend on health insurance status. To investigate this possibility, we created a dichotomous variable taking a value of one if the household is insured and zero otherwise, and included it in the basic models. The results, reported in the fourth panels of Tables $4 \mathrm{a}$ and $4 \mathrm{~b}$, provide little evidence that the relationship between health and portfolio choice depends on the availability of health insurance. In the same spirit, we augmented the basic models with out-of-pocket medical expenditures (including prescription drug payments). In results not reported here, again we find no effect on the portfolio.

\subsubsection{Discussion}

We have examined a number of possible channels through which health might affect portfolio decisions. None of them does a very good job at explaining the strong relationship between health and the probability of owning particular classes of assets. One possibility is that the various attitudinal measures are not good proxies for individuals' true underlying risk preferences, planning horizons, or bequest motives. Alternatively, some entirely different mechanisms might be at work. For example, health status may affect expectations of future income and hence permanent income, which in turn influences investment decisions. This observation is potentially troubling because to the extent wealth is measured with error, health might simply be a proxy for unobserved wealth. While our data do not allow us to investigate this possibility directly, when we

composition or the coefficient on health. To the extent that these expectational variables proxy for optimism, this suggests that optimism is not driving our results. 
estimated our basic models leaving out wealth altogether, we found that the health effects were similar both in magnitude and statistical significance. This implies that our estimated health effect is not merely an artifact of the correlation between health and wealth. We believe that this observation, together with the results in Table 4 and our discussion of "third variables" in Table 3, goes a long way in establishing that there is a robust relationship between health status and portfolio choice, though the channels through which it operates are not entirely clear.

\section{Portfolio Shares}

\subsection{Estimation Issues}

Our next step is to estimate how the shares of the four asset categories that comprise financial wealth depend on health status. The main statistical issue arises from the fact that portfolio shares are bounded by zero and one. Investigators have used a variety of econometric approaches. Heaton and Lucas [2000] discard from their sample individuals whose stock holdings fall below a certain floor and use ordinary least squares estimation. Bertaut and Starr-McCluer [2002] utilize Heckman's [1979] selectivity bias correction to account for the fact that many of the portfolio shares are zeroes. Poterba and Samwick [1999] and Edwards [2002] use a tobit estimator. While each approach has its advantages and disadvantages, we choose the tobit model with truncation at zero. ${ }^{21}$ As before, we pool data from the four waves and estimate the model using random effects, including a year effect for each wave.

\footnotetext{
${ }^{21}$ Poterba and Samwick [1999] and Edwards [2002] employ a two-limit tobit estimator, with truncation at zero and one. However, in our data, none of the assets has a substantial concentration of the portfolio shares at unity, so we use the simpler one-limit version.
} 
It is difficult to find a compelling reason to use a set of covariates different from that in the ownership equations so, following the usual practice, we use the same variables as in Table 3. A technical point arises in this context. When a set of share equations with the same right hand variables is estimated by ordinary least squares, the predicted shares are constrained to add to one, implying that the predicted marginal effects for any given covariate are constrained to sum to zero. The tobit estimator does not automatically impose this constraint. While it is possible to constrain the coefficients in this way, the process is cumbersome. ${ }^{22}$ It turns out that, as a practical matter, in our data the implied marginal effects come close to summing to zero, so we simply present unconstrained estimates. ${ }^{23}$

\subsection{Basic Results}

Following the tack we took with the ownership probabilities, we estimate the share equations separately for singles and married couples. The tobit results are presented in Tables $5 \mathrm{a}$ and $5 \mathrm{~b}$, respectively. Once again, the first column for each asset is the canonical specification and the second column includes controls for occupational history and parents' education. Consider first the health effects for the single individuals. The results indicate that poor health increases the proportion of financial wealth held in safe assets and decreases the proportion held in the other three asset categories. Using the coefficients in the tables, we can compute the marginal effects of poor health on portfolio shares. The specifications in the first columns imply that poor health is associated with an increase of 0.042 in the proportion held in safe assets, a decrease of

\footnotetext{
${ }^{22}$ See Poterba and Samwick [1999] for details. Note that Heckman's two-step procedure does not constrain the predicted shares to equal one.

${ }^{23}$ Specifically, the sum of the marginal health effects comes out to -0.034 for singles, -0.005 for married men and -0.013 for married women.
} 
0.045 held in retirement accounts, a decrease of 0.011 held in bonds, and a decrease of 0.022 held in risky assets. ${ }^{24}$ The addition of more control variables in the second columns does not alter these results.

The health effects for married couples are shown in Table 5b. Once again, poor health for both husbands and wives leads to a higher concentration of safe assets and a lower concentration of virtually all of the other asset categories (the coefficient on husbands' poor health in the equation for bonds is positive but insignificant).

Calculations of the marginal effects for the basic specifications indicate that poor health of a husband is associated with an increase of 0.032 in the proportion held in safe assets, a decrease of 0.030 held in retirement accounts, an increase of 0.003 held in bonds and a decrease of 0.01 held in risky assets. The analogous numbers associated with a wife being in poor health are $0.029,-0.014,-0.007$, and -0.021 . In the second set of columns where we include controls for parents' education, industry and occupation, the results are similar. The basic conclusion is that health is a strong predictor of how a household allocates its financial wealth to different types of assets. Specifically, poor health is associated with less risky portfolios.

\subsection{Mechanisms for Health Effects}

As in the case of ownership probabilities, we next explore possible channels through which health might affect portfolio shares. Following the tack in Tables 4a and $4 \mathrm{~b}$, we incorporate risk preferences, planning horizon, bequest motives, and health insurance into the basic model. The results are presented in Tables $6 \mathrm{a}$ and $6 \mathrm{~b}$ for singles and couples, respectively. Table 6a shows that, in some cases, the additional variables

\footnotetext{
${ }^{24}$ As discussed earlier, the tobit estimator does not constrain the shares to sum to one, which explains the fact that the marginal effects do not sum to zero.
} 
are systematically related to the allocation of financial wealth. For example, from the first panel, individuals who say that they would be willing to take a job with riskier wages hold larger shares of their portfolios in risky assets and smaller shares in safe assets. Likewise, those with longer planning horizons tend to devote a smaller share of their portfolios to safe assets and a larger share in all other types of assets. Importantly, however, the inclusion of none of these variables significantly alters the coefficients on the health status variable. ${ }^{25}$ The results for married couples in Table $6 \mathrm{~b}$ are similar. Hence, as is the case for ownership probabilities, none of these variables sheds much light on the channels through which health affects portfolio shares. However, an intriguing hypothesis is suggested by the theoretical model of Bodie, Merton and Samuelson (BMS) [1992], which posits that individuals vary their labor supply to compensate for the variability in investment returns. BMS view this as an explanation for the fact that older people tend to hold safer portfolios--the ability to compensate ex post for low returns decreases with age. But when an individual is sick, his or her ability to adjust labor supply is similarly diminished; the BMS logic suggests that this, too, should induce a movement toward safer assets, just as our empirical findings suggest.

\section{Summary and Conclusions}

This paper has documented the existence of a strong relationship between health status and portfolio decisions. Even after controlling for the level of total net worth, household income, and a variety of socio-demographic characteristics, poor health decreases the probabilities of owning retirement accounts, bonds, and risky assets.

\footnotetext{
${ }^{25}$ Recall that the models with risk preferences, planning horizons and bequests are estimated only for the first wave, so that the health coefficients are not directly comparable to those in Tables $5 \mathrm{a}$ and $5 \mathrm{~b}$.
} 
Further, those in poor health tend to have relatively safe portfolios -- compared to households that are in good health, the proportion of wealth held in safe assets is higher, while the proportion held in all other asset categories is lower. We find no evidence that the health effects are driven by some third variable that simultaneously influences both health status and financial decision-making.

Although the results suggest that health is an important determinant of portfolio allocation, it is not clear through what channels the effect operates. We explored several possibilities, including risk preferences, bequest motives, planning horizons, and health insurance. However, the inclusion of such variables has very little impact on the magnitude of the health effect. Perhaps the survey responses do not adequately represent individuals' underlying attitudes, or there are other reasons why health affects household portfolio decisions. Exploring alternative mechanisms through which health might affect portfolio choice is an important avenue for future research. We view the notion that poor health reduces the household's ability to increase labor supply to compensate for bad portfolio performance as particularly promising in this context. In any case, the results in this paper suggest that there are potentially important linkages between the health care sector and financial markets. One can imagine, for example, that improvements in medical technology that improve health status will induce changes in portfolio holdings. This observation could be particularly relevant in assessing the financial consequences of the aging of the baby boomers. 


\section{REFERENCES}

Barber, Brad M. and Terrance Odean, "Boys will be Boys: Gender, Overconfidence, and Common Stock Investment," Quarterly Journal of Economics 116 (1), 2001, pp. 261-292.

Bertaut, Carol C. and Martha Starr-McCluer, "Household Pensions in the United States," in Guiso, Luigi, Michael Haliassos, and Tulio Jappelli (eds.), Household Portfolios, MIT Press: Cambridge, MA, 2002.

Bodie, Zvi, Robert C. Merton and William F. Samuelson, "Labor Supply Flexibility and Portfolio Choice in a Life Cycle Model," Journal of Economic Dynamics and Control 16(3-4), 1992, pp. 427-449.

Browning, Martin, "The Saving Behavior of a Two-Person Household," Scandinavian Journal of Economics 102, no. 2, June 2000, pp. 235-251.

Edwards, Ryan D., "Health Risk and Portfolio Choice," Working Paper, University of California, Berkeley, April 2002.

Foldes, Lucien, "Valuation and Martingale Properties of Shadow Prices: An Exposition," Journal of Economic Dynamics and Control 24(11-12), 2000, pp. 16411701.

Gollier, Christian, "What does Theory Have to Say about Household Portfolios?" in Guiso, Luigi, Michael Haliassos, and Tullio Jappelli (eds.), Household Portfolios, MIT Press: Cambridge, MA, 2002.

Guiso, Luigi, Michael Haliassos, and Tullio Jappelli, "Introduction," in Guiso, Luigi, Michael Haliassos, and Tullio Jappelli (eds.), Household Portfolios, MIT Press: Cambridge, MA, 2002.

Heaton, John and Deborah Lucas, "Savings Behavior and Portfolio Choice: Evidence from the Tax Data,” Working Paper, Northwestern University, 1997.

Heaton, John and Deborah Lucas, "Portfolio Choice and Asset Prices: The Importance of Entrepreneurial Risk," Journal of Finance 55(3), 2000, pp.1163-1198.

Heckman, James J., "Sample Selection Bias as a Specification Error," Econometrica 47(1), 1979, pp. 153-161.

Hurd, Michael D., "Portfolio Holdings of the Elderly," in Guiso, Luigi, Michael Haliassos, and Tullio Jappelli (eds.), Household Portfolios, MIT Press: Cambridge, MA, 2002. 
Hurd, Michael and K. McGarry, "Evaluation of the Subjective Probabilities of Survival in the Health and Retirement Survey," Journal of Human Resources 30(5), 1995, pp. S268-292.

Idler, Ellen and Yael Benyamini, "Self-Related Health and Mortality: A Review of Twenty-Seven Community Studies," Journal of Health and Social Behavior 38(1), 1997, pp. 21-37.

King, Mervyn A. and Jonathan I. Leape, "Wealth and Portfolio Composition: Theory and Evidence," Journal of Public Economics 69(2), 1998, pp. 155-193.

Lott, John R. and Lawrence W. Kenny, “Did Women's Suffrage Change the Size and Scope of Government?” Journal of Political Economy 107(6), 1999, pp. 1163-1198.

Maddala, G.S., Limited-Dependent and Qualitative Variables in Econometrics, Cambridge University Press: New York, 1983.

Mazzocco, Maurizio, "Savings, Risk Sharing and Preferences for Risk," Working Paper, University of Wisconsin, 2002.

Mossin, Jan, "Taxation and Risk Taking: An Expected Utility Approach," Economica 35(1), 1968, pp. 74-82.

Poterba, James M., "Government Saving Incentives in the United States," in James M. Poterba (ed.), Public Policies and Household Saving, The University of Chicago Press: Chicago, 1994, pp. 1-18.

Poterba, James M., "Taxation and Portfolio Structure: Issues and Implications," Working Paper 8223, National Bureau of Economic Research, 2001.

Poterba, James M. and Andrew A. Samwick, "Taxation and Household Portfolio Composition: U.S. Evidence from the 1980's and 1990's," Working Paper 7392, National Bureau of Economic Research, October, 1999.

Schmidt, N.B., M.J. Telch and T.E. Joiner, "Factors Influencing Health Perceptions in Patients with Panic Disorder," Comprehensive Psychiatry 37(4), JulyAugust 1996, pp. 253-260.

Smith, James P., "Healthy Bodies and Thick Wallets: The Dual Relation Between Health and Economic Status,' Journal of Economic Perspectives 13(2), 1999, pp. 145-166.

Tobin, James, "Liquidity Preference as Behavior Toward Risk, "Review of Economic Studies 25(2), 1958, pp. 65-86. 
Venti, Steven F. and David A. Wise, "Choice, Chance, and Wealth Dispersion at Retirement," Working Paper 7521, National Bureau of Economic Research, 2000.

Wu, Stephen, "The Effects of Health Events on the Economic Status of Married Couples," Journal of Human Resources, 2003, forthcoming. 
Table 1: Summary Statistics

\begin{tabular}{|c|c|c|}
\hline Variable & $\underline{\text { Singles }}$ & Married Couples \\
\hline Age (Singles) & 58.959 & $\ldots$ \\
\hline Husband Age & $\ldots$ & 60.471 \\
\hline Wife Age & $\cdots$ & 56.451 \\
\hline Education (Singles) & 12.079 & $\ldots$ \\
\hline Husband Education & $\ldots$ & 12.405 \\
\hline Wife Education & $\cdots$ & 12.358 \\
\hline Proportion Black (Singles) & 0.175 & $\ldots$ \\
\hline Husband Black & $\ldots$ & 0.063 \\
\hline Wife Black & $\cdots$ & 0.057 \\
\hline Proportion Female (Singles) & 0.584 & $\ldots$ \\
\hline Proportion Sick (Singles) & 0.284 & $\ldots$ \\
\hline Husband Sick & $\ldots$ & 0.199 \\
\hline Wife Sick & $\cdots$ & 0.172 \\
\hline Proportion With Any Children & 0.801 & 0.969 \\
\hline Household Income & 20,398 & 34,763 \\
\hline Financial Assets & 38,548 & 94,915 \\
\hline Total Net Worth & 164,683 & 314,300 \\
\hline Have Safe Asset & 0.673 & 0.803 \\
\hline Have Retirement Account & 0.285 & 0.457 \\
\hline Have Bond & 0.043 & 0.073 \\
\hline Have Risky Asset & 0.203 & 0.327 \\
\hline Have Some Financial Assets & 0.705 & 0.841 \\
\hline $\mathrm{N}$ & 7,460 & 15,920 \\
\hline \multicolumn{3}{|c|}{ Conditional on Having Some Financial Assets } \\
\hline Proportion in Safe Assets & 0.644 & 0.542 \\
\hline Proportion in Retirement Accounts & 0.204 & 0.271 \\
\hline Proportion in Bonds & 0.014 & 0.019 \\
\hline Proportion in Risky Assets & 0.138 & 0.168 \\
\hline $\mathrm{N}$ & 4,838 & 12,984 \\
\hline
\end{tabular}

Notes: Data source is Waves 1-4 of the HRS. Safe assets include checking, savings and money market accounts, CDs, government savings bonds, and T-bills. Retirement accounts include IRA and Keogh accounts. Bonds include all corporate, municipal and foreign bonds and bond funds. Risky assets include individual stocks and mutual funds. Financial assets are the sum of safe assets, retirement accounts, bonds and risky assets. Total net worth includes all housing and nonhousing equity in addition to financial assets. An individual is classified as "sick" if (s)he reports being in fair or poor health. Means are calculated using household weights provided in the HRS. 
Table 2: Self-Reported Health Status and Portfolio Decisions

\begin{tabular}{|c|c|c|c|c|c|c|c|c|}
\hline & \multicolumn{4}{|c|}{ Probability of Holding Asset } & \multicolumn{4}{|c|}{ Proportion Held in Asset Category } \\
\hline & $\underline{\text { Retirement }}$ & Bond & Risky & Financial & $\underline{\text { Safe }}$ & Retirement & Bond & $\underline{\text { Risky }}$ \\
\hline & & & & & & & & \\
\hline \multicolumn{9}{|l|}{ Health Status } \\
\hline Healthy & 0.354 & 0.054 & 0.251 & 0.778 & 0.608 & 0.226 & 0.015 & 0.151 \\
\hline \multirow[t]{2}{*}{ Sick } & 0.111 & 0.015 & 0.082 & 0.521 & 0.782 & 0.122 & 0.007 & 0.090 \\
\hline & \multirow{2}{*}{\multicolumn{8}{|c|}{ Married Couples }} \\
\hline Health Status & & & & & & & & \\
\hline Both Healthy & 0.526 & 0.088 & 0.385 & 0.879 & 0.495 & 0.296 & 0.020 & 0.189 \\
\hline One Spouse Sick & 0.323 & 0.045 & 0.214 & 0.780 & 0.650 & 0.211 & 0.016 & 0.123 \\
\hline Both Spouses Sick & 0.213 & 0.024 & 0.122 & 0.654 & 0.747 & 0.178 & 0.009 & 0.066 \\
\hline
\end{tabular}

Notes: An individual is classified as "healthy" if (s)he reports having excellent, very good or good health. An individual is classified as "sick" if (s)he reports having fair or poor health. Proportions held in particular asset categories are calculated only for those with positive financial wealth. 
Table 3a: Probit Models for Ownership Probabilities - Singles

Dependent Variable is the Probability of Owning Particular Types of Assets

\begin{tabular}{|c|c|c|c|c|c|c|}
\hline \multirow[b]{2}{*}{ Explanatory Variable } & \multicolumn{2}{|c|}{$\underline{\text { Retirement }}$} & \multicolumn{2}{|c|}{ Bonds } & \multicolumn{2}{|c|}{ Risky Assets } \\
\hline & $(\overline{1)}$ & $(2)$ & (1) & (2) & $(1)$ & $(2)$ \\
\hline \multirow[t]{2}{*}{ Sick } & -0.551 & -0.485 & -0.239 & -0.258 & -0.406 & -0.337 \\
\hline & $(0.100)$ & $(0.109)$ & $(0.122)$ & $(0.132)$ & $(0.094)$ & $(0.101)$ \\
\hline Age & $\begin{array}{c}0.075 \\
(0.022)\end{array}$ & $\begin{array}{c}0.085 \\
(0.020)\end{array}$ & $\begin{array}{c}0.032 \\
(0.014)\end{array}$ & $\begin{array}{c}0.042 \\
(0.015)\end{array}$ & 0.006 & $\begin{array}{c}0.014 \\
0\end{array}$ \\
\hline \multirow[t]{2}{*}{ High School } & 1.559 & 1.303 & 0.391 & 0.197 & 1.158 & 1.019 \\
\hline & $(0.168)$ & $(0.200)$ & $(0.159)$ & $(0.175)$ & $(0.149)$ & $(0.169)$ \\
\hline \multirow[t]{2}{*}{ Some College } & 2.315 & 1.895 & 0.688 & 0.415 & 1.856 & 1.672 \\
\hline & $(0.206)$ & $(0.224)$ & $(0.169)$ & $(0.185)$ & $(0.165)$ & $(0.183)$ \\
\hline \multirow[t]{2}{*}{ College } & 2.306 & 1.909 & 0.964 & 0.645 & 2.059 & 1.827 \\
\hline & $(0.242)$ & $(0.273)$ & $(0.198)$ & $(0.214)$ & $(0.205)$ & $(0.224)$ \\
\hline \multirow[t]{2}{*}{ Post College } & 2.695 & 2.180 & 1.150 & 0.737 & 2.207 & 1.863 \\
\hline & $(0.217)$ & $(0.259)$ & $(0.184)$ & $(0.204)$ & $(0.193)$ & $(0.215)$ \\
\hline \multirow[t]{2}{*}{ Net Worth/(10^6) } & 1.199 & 1.155 & 0.758 & 0.701 & 1.176 & 1.117 \\
\hline & $(0.116)$ & $(0.120)$ & $(0.106)$ & $(0.109)$ & $(0.110)$ & $(0.115)$ \\
\hline \multirow[t]{2}{*}{ Net Worth Squared /(10^12) } & -0.172 & -0.157 & -0.043 & -0.038 & -0.082 & -0.078 \\
\hline & $(0.016)$ & $(0.018)$ & $(0.011)$ & $(0.011)$ & $(0.012)$ & $(0.012)$ \\
\hline \multirow[t]{2}{*}{$\mathrm{HH}$ Income/(10^6) } & 9.236 & 7.969 & 2.283 & 2.357 & 4.254 & 3.983 \\
\hline & $(1.026)$ & (1.133) & $(1.066)$ & $(1.071)$ & $(0.086$ & $(0.862)$ \\
\hline \multirow[t]{2}{*}{ HH Income Squared/(10^12) } & -0.841 & -0.727 & -0.441 & -0.471 & -0.403 & -0.378 \\
\hline & $(0.094)$ & $(0.102)$ & $(0.061)$ & $(0.612)$ & $(0.081)$ & $(0.081)$ \\
\hline \multirow[t]{2}{*}{ Black } & -1.046 & -1.108 & -0.120 & 0.004 & -0.929 & -0.832 \\
\hline & $(0.236)$ & $(0.267)$ & $(0.232)$ & $(0.242)$ & $(0.239)$ & $(0.259)$ \\
\hline \multirow[t]{2}{*}{ Have Kids } & -0.561 & -0.538 & -0.091 & -0.124 & -0.046 & -0.052 \\
\hline & $(0.165)$ & $(0.162)$ & $(0.119)$ & $(0.123)$ & $(0.121)$ & $(0.127)$ \\
\hline \multirow[t]{2}{*}{ Female } & -0.251 & -0.266 & -0.145 & -0.077 & -0.402 & -0.338 \\
\hline & $(0.136)$ & $(0.145)$ & $(0.115)$ & $(0.119)$ & $(0.111)$ & $(0.117)$ \\
\hline \multirow[t]{2}{*}{ Constant } & -7.681 & -7.894 & -5.164 & -5.848 & -3.443 & -4.408 \\
\hline & $(1.402)$ & $(1.159)$ & $(0.955)$ & $(0.937)$ & $(0.870)$ & $(0.876)$ \\
\hline \multirow{2}{*}{$\begin{array}{l}\text { Controls for Year Effects? } \\
\text { Controls for Industry, Occupation, } \\
\text { and Parents' Education? }\end{array}$} & Yes & Yes & Yes & Yes & Yes & Yes \\
\hline & No & Yes & No & Yes & No & Yes \\
\hline $\mathrm{N}$ & 7,356 & 5,993 & 7,356 & 5,993 & 7,356 & 5,993 \\
\hline
\end{tabular}

Notes: Estimation is by random effects. Due to missing information on family background, industry and occupation, sample sizes differ between first and second columns of each regression. For bonds, the regression in the second column only includes parents' education in order to preserve a sufficient number of observations. Standard errors are in parentheses. 
Table 3b: Probit Models for Ownership Probabilities - Married Couples Dependent Variable is the Probability of Owning Particular Types of Assets

\begin{tabular}{|c|c|c|c|c|c|c|}
\hline \multirow[b]{2}{*}{ Explanatory Variable } & \multicolumn{2}{|c|}{$\underline{\text { Retirement }}$} & \multicolumn{2}{|c|}{ Bonds } & \multicolumn{2}{|c|}{ Risky Assets } \\
\hline & $(\overline{1)}$ & $(2)$ & $(1)$ & $(2)$ & (1) & $(2)$ \\
\hline \multirow[t]{2}{*}{ Husband Sick } & -0.270 & -0.236 & 0.062 & 0.015 & -0.134 & -0.085 \\
\hline & $(0.057)$ & $(0.066)$ & $(0.078)$ & (0.091) & (0.053) & $(0.060)$ \\
\hline Wife Sick & $\begin{array}{c}-0.194 \\
(0.063)\end{array}$ & $\begin{array}{l}-0.206 \\
(0.075)\end{array}$ & $\begin{array}{l}-0.193 \\
(0.094)\end{array}$ & $\begin{array}{c}-0.176 \\
(0.108)\end{array}$ & $\begin{array}{l}-0.213 \\
(0.060)\end{array}$ & $\begin{array}{c}-0.139 \\
(0.069)\end{array}$ \\
\hline \multirow[t]{2}{*}{ Husband Age } & 0.018 & 0.021 & 0.013 & 0.003 & 0.003 & 0.004 \\
\hline & $(0.007)$ & $(0.008)$ & $(0.008)$ & $(0.009)$ & $(0.006)$ & $(0.007)$ \\
\hline \multirow[t]{2}{*}{ Wife Age } & 0.051 & 0.043 & 0.016 & 0.019 & 0.029 & 0.030 \\
\hline & $(0.008)$ & $(0.009)$ & $(0.007)$ & $(0.008)$ & $(0.006)$ & $(0.007)$ \\
\hline \multirow[t]{2}{*}{ Husband HS } & 0.877 & 0.977 & 0.457 & 0.446 & 0.628 & 0.553 \\
\hline & $(0.102)$ & $(0.129)$ & $(0.114)$ & $(0.143)$ & $(0.084)$ & $(0.102)$ \\
\hline \multirow[t]{2}{*}{ Wife HS } & 1.008 & 0.910 & 0.662 & 0.690 & 0.856 & 0.836 \\
\hline & $(0.108)$ & $(0.133)$ & $(0.126)$ & $(0.159)$ & $(0.088)$ & $(0.109)$ \\
\hline \multirow[t]{2}{*}{ Husband Some College } & 0.854 & 0.928 & 0.582 & 0.547 & 0.996 & 0.839 \\
\hline & $(0.125)$ & $(0.151)$ & $(0.127)$ & $(0.156)$ & $(0.097)$ & $(0.115)$ \\
\hline \multirow[t]{2}{*}{ Wife Some College } & 1.309 & 1.149 & 0.642 & 0.635 & 0.990 & 0.882 \\
\hline & $(0.122)$ & $(0.153)$ & $(0.139)$ & $(0.172)$ & $(0.101)$ & $(0.123)$ \\
\hline \multirow[t]{2}{*}{ Husband College } & 1.192 & 1.153 & 0.856 & 0.804 & 1.195 & 1.018 \\
\hline & $(0.139)$ & $(0.166)$ & $(0.139)$ & $(0.169)$ & $(0.114)$ & $(0.132)$ \\
\hline \multirow[t]{2}{*}{ Wife College } & 1.438 & 1.269 & 0.835 & 0.848 & 1.117 & 0.943 \\
\hline & $(0.165)$ & $(0.191)$ & $(0.164)$ & $(0.198)$ & $(0.133)$ & $(0.156)$ \\
\hline \multirow[t]{2}{*}{ Husband Post College } & 1.238 & 1.247 & 1.102 & 1.055 & 1.009 & 0.838 \\
\hline & $(0.147)$ & $(0.175)$ & $(0.139)$ & $(0.168)$ & $(0.114)$ & $(0.133)$ \\
\hline \multirow[t]{2}{*}{ Wife Post College } & 1.391 & 1.193 & 0.779 & 0.775 & 0.991 & 0.841 \\
\hline & $(0.165)$ & $(0.196)$ & $(0.165)$ & $(0.199)$ & $(0.135)$ & $(0.156)$ \\
\hline \multirow[t]{2}{*}{ Net Worth/(10^6) } & 1.249 & 1.227 & 0.940 & 0.935 & 1.174 & 1.189 \\
\hline & $(0.075)$ & $(0.084)$ & $(0.076)$ & $(0.082)$ & $(0.065)$ & $(0.070)$ \\
\hline \multirow{2}{*}{ Net Worth Squared/(10^12) } & -0.151 & -0.146 & -0.100 & -0.099 & -0.115 & -0.115 \\
\hline & $(0.014)$ & $(0.014)$ & $(0.013)$ & $(0.014)$ & $(0.011)$ & $(0.012)$ \\
\hline \multirow[t]{2}{*}{$\mathrm{HH}$ Income/(10^6) } & 7.245 & 6.987 & 2.012 & 1.637 & 3.522 & 3.321 \\
\hline & $(0.620)$ & $(0.676)$ & $(0.541)$ & $(0.580)$ & $(0.502)$ & $(0.553)$ \\
\hline \multirow[t]{2}{*}{ HH Income Squared/(10^12) } & -3.244 & -3.104 & -0.832 & -0.646 & -1.766 & -1.565 \\
\hline & $(0.427)$ & $(0.453)$ & $(0.341)$ & $(0.347)$ & $(0.363)$ & $(0.401)$ \\
\hline \multirow[t]{2}{*}{ Husband Black } & -1.274 & -1.260 & -0.636 & -0.625 & -0.965 & -0.856 \\
\hline & $(0.118)$ & $(0.152)$ & $(0.151)$ & $(0.185)$ & $(0.106)$ & $(0.126)$ \\
\hline \multirow[t]{2}{*}{ Have Kids } & -0.095 & -0.171 & -0.182 & 0.020 & -0.051 & 0.180 \\
\hline & $(0.218)$ & $(0.273)$ & $(0.181)$ & $(0.216)$ & $(0.166)$ & $(0.193)$ \\
\hline \multirow[t]{2}{*}{ Constant } & -6.322 & -6.334 & -5.347 & -5.450 & -4.574 & -5.568 \\
\hline & $(0.506)$ & $(0.593)$ & $(0.495)$ & $(0.583)$ & $(0.401)$ & $(0.479)$ \\
\hline \multirow{2}{*}{$\begin{array}{l}\text { Controls for Year Effects? } \\
\text { Controls for Industry, Occupation, } \\
\text { and Parents' Education? }\end{array}$} & Yes & Yes & Yes & Yes & Yes & Yes \\
\hline & No & Yes & No & Yes & No & Yes \\
\hline $\mathrm{N}$ & 15,756 & 12,194 & 15,756 & 12,194 & 15,756 & 12,194 \\
\hline
\end{tabular}

Notes: Estimation is by random effects. Due to missing information on family background, industry and occupation, sample sizes differ between first and second columns of each regression. For bonds, the regression in the second column only includes parents' education in order to preserve a sufficient number of observations. Standard errors are in parentheses. 
Table 4a: Probit Models for Ownership Probabilities - Alternative Specifications for Singles Dependent Variable is the Probability of Owning Particular Types of Assets

\begin{tabular}{|c|c|c|c|}
\hline Explanatory Variable & Retirement & Bonds & Risky Assets \\
\hline & \multicolumn{3}{|c|}{$\underline{\text { Risk Preferences }}$} \\
\hline Sick & $\begin{array}{l}-0.454 \\
(0.082)\end{array}$ & $\begin{array}{c}-0.557 \\
(0.193)\end{array}$ & $\begin{array}{l}-0.466 \\
(0.097)\end{array}$ \\
\hline Risk Taker & $\begin{array}{l}-0.079 \\
(0.073)\end{array}$ & $\begin{array}{l}-0.137 \\
(0.130)\end{array}$ & $\begin{array}{c}0.139 \\
(0.079)\end{array}$ \\
\hline \multirow[t]{2}{*}{$\mathrm{N}$} & 2,545 & 2,545 & 2,545 \\
\hline & \multicolumn{3}{|c|}{$\underline{\text { Planning Horizon }}$} \\
\hline Sick & $\begin{array}{l}-0.402 \\
(0.084)\end{array}$ & $\begin{array}{c}-0.393 \\
(0.184)\end{array}$ & $\begin{array}{l}-0.385 \\
(0.098)\end{array}$ \\
\hline \multicolumn{4}{|l|}{ Planning Horizon } \\
\hline Next Year & $\begin{array}{c}0.000 \\
(0.126)\end{array}$ & $\begin{array}{c}0.350 \\
(0.248)\end{array}$ & $\begin{array}{l}-0.057 \\
(0.146)\end{array}$ \\
\hline Next Few Years & $\begin{array}{c}0.266 \\
(0.090)\end{array}$ & $\begin{array}{c}0.378 \\
(0.197)\end{array}$ & $\begin{array}{c}0.236 \\
(0.104)\end{array}$ \\
\hline Next 5-10 Years & $\begin{array}{c}0.354 \\
(0.093)\end{array}$ & $\begin{array}{c}0.455 \\
(0.198)\end{array}$ & $\begin{array}{c}0.439 \\
(0.105)\end{array}$ \\
\hline More Than 10 Years & $\begin{array}{c}0.320 \\
(0.130)\end{array}$ & $\begin{array}{c}0.565 \\
(0.234)\end{array}$ & $\begin{array}{c}0.341 \\
(0.144)\end{array}$ \\
\hline \multirow[t]{2}{*}{$\mathrm{N}$} & 2,488 & 2,488 & 2,488 \\
\hline & \multicolumn{3}{|c|}{ Bequest Motive } \\
\hline Sick & $\begin{array}{l}-0.416 \\
(0.083)\end{array}$ & $\begin{array}{c}-0.447 \\
(0.185)\end{array}$ & $\begin{array}{l}-0.454 \\
(0.098)\end{array}$ \\
\hline \multicolumn{4}{|c|}{ Likelihood of Leaving Bequest } \\
\hline Definitely & $\begin{array}{c}0.199 \\
(0.106)\end{array}$ & $\begin{array}{c}0.135 \\
(0.181)\end{array}$ & $\begin{array}{c}0.278 \\
(0.113)\end{array}$ \\
\hline Probably & $\begin{array}{c}0.326 \\
(0.104)\end{array}$ & $\begin{array}{c}0.094 \\
(0.188)\end{array}$ & $\begin{array}{c}0.383 \\
(0.112)\end{array}$ \\
\hline Possibly & $\begin{array}{c}0.270 \\
(0.100)\end{array}$ & $\begin{array}{c}0.393 \\
(0.166)\end{array}$ & $\begin{array}{c}0.183 \\
(0.112)\end{array}$ \\
\hline Probably Not & $\begin{array}{c}0.276 \\
(0.083)\end{array}$ & $\begin{array}{c}0.043 \\
(0.164)\end{array}$ & $\begin{array}{c}0.117 \\
(0.096)\end{array}$ \\
\hline \multirow[t]{2}{*}{ N } & 2,591 & 2,591 & 2,591 \\
\hline & \multicolumn{3}{|c|}{ Health Insurance } \\
\hline Sick & $\begin{array}{l}-0.549 \\
(0.100)\end{array}$ & $\begin{array}{c}-0.239 \\
(0.122)\end{array}$ & $\begin{array}{l}-0.407 \\
(0.093)\end{array}$ \\
\hline Insured & $\begin{array}{c}0.079 \\
(0.091)\end{array}$ & $\begin{array}{c}0.079 \\
(0.110)\end{array}$ & $\begin{array}{c}0.170 \\
(0.084)\end{array}$ \\
\hline $\mathrm{N}$ & 7,356 & 7,356 & 7,356 \\
\hline
\end{tabular}

Notes: All regressions include controls for age, education, race, sex, household income, total net worth, the presence of children and a constant term as in Table $3 a$. The models that include health insurance information are random-effects probits using 4 waves of data and including time effects, while all other models are crosssection regressions using wave 1 data (since these questions are not asked in other waves). Omitted category for planning horizon is "a few months". Omitted category for bequest motive is "definitely not". Standard errors are in parentheses. 
Table 4b: Probit Models for Ownership Probabilities - Alternative Specifications for Married Couples Dependent Variable is the Probability of Owning Particular Types of Assets

\begin{tabular}{|c|c|c|c|}
\hline Explanatory Variable & $\underline{\text { Retirement }}$ & Bonds & Risky Assets \\
\hline & \multicolumn{3}{|c|}{$\underline{\text { Risk Preferences }}$} \\
\hline Husband Sick & $\begin{array}{l}-0.296 \\
(0.060)\end{array}$ & $\begin{array}{l}-0.019 \\
(0.104)\end{array}$ & $\begin{array}{l}-0.098 \\
(0.063)\end{array}$ \\
\hline Wife Sick & $\begin{array}{l}-0.159 \\
(0.064)\end{array}$ & $\begin{array}{l}-0.391 \\
(0.137)\end{array}$ & $\begin{array}{l}-0.259 \\
(0.069)\end{array}$ \\
\hline Husband Risk Taker & $\begin{array}{l}-0.043 \\
(0.052)\end{array}$ & $\begin{array}{c}0.032 \\
(0.077)\end{array}$ & $\begin{array}{c}0.067 \\
(0.053)\end{array}$ \\
\hline Wife Risk Taker & $\begin{array}{l}-0.015 \\
(0.053)\end{array}$ & $\begin{array}{c}0.074 \\
(0.078)\end{array}$ & $\begin{array}{l}-0.026 \\
(0.054)\end{array}$ \\
\hline $\mathrm{N}$ & \multicolumn{3}{|c|}{ Planning Horizon } \\
\hline Husband Sick & $\begin{array}{l}-0.256 \\
(0.061)\end{array}$ & $\begin{array}{l}-0.060 \\
(0.109)\end{array}$ & $\begin{array}{l}-0.070 \\
(0.064)\end{array}$ \\
\hline Wife Sick & $\begin{array}{l}-0.118 \\
(0.065)\end{array}$ & $\begin{array}{l}-0.339 \\
(0.139)\end{array}$ & $\begin{array}{l}-0.251 \\
(0.070)\end{array}$ \\
\hline \multicolumn{4}{|c|}{ Husband Planning Horizon } \\
\hline Next Year & $\begin{array}{c}0.129 \\
(0.092)\end{array}$ & $\begin{array}{c}0.043 \\
(0.154)\end{array}$ & $\begin{array}{c}0.036 \\
(0.096)\end{array}$ \\
\hline Next Few Years & $\begin{array}{c}0.212 \\
(0.071)\end{array}$ & $\begin{array}{c}0.004 \\
(0.122)\end{array}$ & $\begin{array}{c}0.119 \\
(0.074)\end{array}$ \\
\hline Next 5-10 Years & $\begin{array}{c}0.273 \\
(0.073)\end{array}$ & $\begin{array}{c}0.114 \\
(0.122)\end{array}$ & $\begin{array}{c}0.183 \\
(0.075)\end{array}$ \\
\hline More Than 10 Years & $\begin{array}{c}0.351 \\
(0.096)\end{array}$ & $\begin{array}{c}0.327 \\
(0.141)\end{array}$ & $\begin{array}{c}0.335 \\
(0.096)\end{array}$ \\
\hline \multicolumn{4}{|l|}{ Wife Planning Horizon } \\
\hline Next Year & $\begin{array}{l}-0.056 \\
(0.087)\end{array}$ & $\begin{array}{l}-0.046 \\
(0.151)\end{array}$ & $\begin{array}{l}-0.110 \\
(0.089)\end{array}$ \\
\hline Next Few Years & $\begin{array}{c}0.167 \\
(0.068)\end{array}$ & $\begin{array}{c}0.067 \\
(0.114)\end{array}$ & $\begin{array}{l}-0.086 \\
(0.070)\end{array}$ \\
\hline Next 5-10 Years & $\begin{array}{c}0.271 \\
(0.071)\end{array}$ & $\begin{array}{c}0.091 \\
(0.117)\end{array}$ & $\begin{array}{c}0.035 \\
(0.072)\end{array}$ \\
\hline More Than 10 Years & $\begin{array}{c}0.299 \\
(0.095)\end{array}$ & $\begin{array}{c}0.112 \\
(0.140)\end{array}$ & $\begin{array}{c}0.102 \\
(0.095)\end{array}$ \\
\hline $\mathrm{N}$ & \multicolumn{3}{|c|}{ Bequest Motive } \\
\hline Husband Sick & $\begin{array}{l}-0.276 \\
(0.055)\end{array}$ & $\begin{array}{l}-0.043 \\
(0.097)\end{array}$ & $\begin{array}{l}-0.097 \\
(0.058)\end{array}$ \\
\hline Wife Sick & $\begin{array}{l}-0.196 \\
(0.058)\end{array}$ & $\begin{array}{l}-0.341 \\
(0.124)\end{array}$ & $\begin{array}{l}-0.258 \\
(0.063)\end{array}$ \\
\hline Likelihood of Leaving & & & \\
\hline Definitely & $\begin{array}{c}0.086 \\
(0.073)\end{array}$ & $\begin{array}{c}0.233 \\
(0.106)\end{array}$ & $\begin{array}{c}0.245 \\
(0.074)\end{array}$ \\
\hline Probably & $\begin{array}{c}0.242 \\
(0.064)\end{array}$ & $\begin{array}{c}0.120 \\
(0.099)\end{array}$ & $\begin{array}{c}0.228 \\
(0.065)\end{array}$ \\
\hline Possibly & $\begin{array}{c}0.176 \\
(0.065)\end{array}$ & $\begin{array}{c}0.183 \\
(0.103)\end{array}$ & $\begin{array}{c}0.233 \\
(0.067)\end{array}$ \\
\hline Probably Not & $\begin{array}{c}0.124 \\
(0.056)\end{array}$ & $\begin{array}{l}-0.029 \\
(0.098)\end{array}$ & $\begin{array}{c}0.120 \\
(0.059)\end{array}$ \\
\hline $\mathrm{N}$ & 4,880 & 4,880 & 4,880 \\
\hline
\end{tabular}


Table 4b (continued): Probit Models for Ownership Probabilities - Alternative Specifications for Married Couples Dependent Variable is the Probability of Owning Particular Types of Assets

\begin{tabular}{|c|c|c|c|}
\hline Explanatory Variable & Retirement & Bonds & Risky Assets \\
\hline & \multicolumn{3}{|c|}{$\underline{\text { Health Insurance }}$} \\
\hline Husband Sick & $\begin{array}{c}-0.277 \\
(0.057)\end{array}$ & $\begin{array}{c}0.062 \\
(0.078)\end{array}$ & $\begin{array}{c}-0.139 \\
(0.053)\end{array}$ \\
\hline Wife Sick & $\begin{array}{l}-0.197 \\
(0.063)\end{array}$ & $\begin{array}{l}-0.193 \\
(0.094)\end{array}$ & $\begin{array}{c}-0.216 \\
(0.060)\end{array}$ \\
\hline Couple Insured & $\begin{array}{c}0.245 \\
(0.068)\end{array}$ & $\begin{array}{l}-0.031 \\
(0.087)\end{array}$ & $\begin{array}{c}0.197 \\
(0.063)\end{array}$ \\
\hline $\mathrm{N}$ & 15,756 & 15,756 & 15,756 \\
\hline
\end{tabular}

Notes: All regressions include controls for age, education, race, sex, household income, total net worth, the presence of children and a constant term as in Table $3 \mathrm{~b}$. The models that include health insurance information are random-effects probits using 4 waves of data and including time effects, while all other models are crosssection regressions using wave 1 data (since these questions are not asked in other waves). Omitted category for planning horizon is "a few months". Omitted category for bequest motive is "definitely not". Standard errors are in parentheses. 
Table 5a: Tobit Regressions of Portfolio Shares - Singles

Dependent Variable is the Share of Financial Wealth Held in a Particular Asset

\begin{tabular}{|c|c|c|c|c|c|c|c|c|}
\hline \multirow[b]{2}{*}{ Explanatory Variable } & \multicolumn{2}{|c|}{ Safe Assets } & \multicolumn{2}{|c|}{$\underline{\text { Retirement }}$} & \multicolumn{2}{|c|}{ Bonds } & \multicolumn{2}{|c|}{ Risky Assets } \\
\hline & (1) & (2) & (1) & (2) & (1) & (2) & (1) & (2) \\
\hline Sick & 0.048 & 0.044 & -0.174 & -0.164 & -0.089 & -0.084 & -0.099 & $\begin{array}{l}-0.076 \\
(0.041)\end{array}$ \\
\hline Age & -0.002 & -0.004 & 0.007 & 0.011 & 0.012 & 0.015 & 0.001 & $\begin{array}{c}0.004 \\
(0.006)\end{array}$ \\
\hline High School & $\begin{array}{l}-0.133 \\
(0.210)\end{array}$ & $\begin{array}{l}-0.118 \\
(0.025)\end{array}$ & $\begin{array}{c}0.404 \\
(0.055)\end{array}$ & $\begin{array}{c}0.359 \\
(0.067)\end{array}$ & $\begin{array}{c}0.092 \\
(0.060)\end{array}$ & $\begin{array}{c}0.026 \\
(0.065)\end{array}$ & $\begin{array}{c}0.404 \\
(0.064)\end{array}$ & $\begin{array}{c}0.344 \\
(0.070)\end{array}$ \\
\hline Some College & $\begin{array}{l}-0.234 \\
(0.234)\end{array}$ & $\begin{array}{l}-0.209 \\
(0.028)\end{array}$ & $\begin{array}{c}0.588 \\
(0.062)\end{array}$ & $\begin{array}{c}0.507 \\
(0.074)\end{array}$ & $\begin{array}{c}0.148 \\
(0.063)\end{array}$ & $\begin{array}{c}0.059 \\
(0.069)\end{array}$ & $\begin{array}{c}0.673 \\
(0.068)\end{array}$ & $\begin{array}{c}0.609 \\
(0.074)\end{array}$ \\
\hline College & $\begin{array}{l}-0.269 \\
(0.031)\end{array}$ & $\begin{array}{l}-0.245 \\
(0.035)\end{array}$ & $\begin{array}{c}0.593 \\
(0.072)\end{array}$ & $\begin{array}{c}0.520 \\
(0.081)\end{array}$ & $\begin{array}{c}0.260 \\
(0.071)\end{array}$ & $\begin{array}{c}0.143 \\
(0.077)\end{array}$ & $\begin{array}{c}0.737 \\
(0.079)\end{array}$ & $\begin{array}{c}0.646 \\
(0.089)\end{array}$ \\
\hline Post College & $\begin{array}{l}-0.286 \\
(0.028)\end{array}$ & $\begin{array}{l}-0.249 \\
(0.032)\end{array}$ & $\begin{array}{c}0.614 \\
(0.066)\end{array}$ & $\begin{array}{c}0.549 \\
(0.078)\end{array}$ & $\begin{array}{c}0.330 \\
(0.066)\end{array}$ & $\begin{array}{c}0.183 \\
(0.073)\end{array}$ & $\begin{array}{c}0.764 \\
(0.078)\end{array}$ & $\begin{array}{c}0.626 \\
(0.088)\end{array}$ \\
\hline Net Worth/(10^6) & $\begin{array}{l}-0.165 \\
(0.017)\end{array}$ & $\begin{array}{l}-0.161 \\
(0.018)\end{array}$ & $\begin{array}{c}0.125 \\
(0.031)\end{array}$ & $\begin{array}{c}0.116 \\
(0.032)\end{array}$ & $\begin{array}{c}0.300 \\
(0.040)\end{array}$ & $\begin{array}{c}0.282 \\
(0.040)\end{array}$ & $\begin{array}{c}0.334 \\
(0.036)\end{array}$ & $\begin{array}{c}0.311 \\
(0.034)\end{array}$ \\
\hline Net Worth Squared/(10^12) & $\begin{array}{c}0.013 \\
(0.002)\end{array}$ & $\begin{array}{c}0.012 \\
(0.002)\end{array}$ & $\begin{array}{l}-0.020 \\
(0.004)\end{array}$ & $\begin{array}{l}-0.018 \\
(0.005)\end{array}$ & $\begin{array}{l}-0.017 \\
(0.004)\end{array}$ & $\begin{array}{l}-0.016 \\
(0.004)\end{array}$ & $\begin{array}{l}-0.023 \\
(0.004)\end{array}$ & $\begin{array}{l}-0.021 \\
(0.004)\end{array}$ \\
\hline $\mathrm{HH}$ Income/(10^6) & $\begin{array}{l}-0.399 \\
(0.114)\end{array}$ & $\begin{array}{l}-0.353 \\
(0.117)\end{array}$ & $\begin{array}{c}0.967 \\
(0.237)\end{array}$ & $\begin{array}{c}0.879 \\
(0.236)\end{array}$ & $\begin{array}{c}0.311 \\
(0.378)\end{array}$ & $\begin{array}{c}0.336 \\
(0.380)\end{array}$ & $\begin{array}{c}0.534 \\
(0.214)\end{array}$ & $\begin{array}{c}0.501 \\
(0.211)\end{array}$ \\
\hline HH Income Squared/(10^12) & $\begin{array}{c}0.041 \\
(0.011)\end{array}$ & $\begin{array}{c}0.037 \\
(0.011)\end{array}$ & $\begin{array}{l}-0.090 \\
(0.022)\end{array}$ & $\begin{array}{l}-0.082 \\
(0.022)\end{array}$ & $\begin{array}{l}-0.061 \\
(0.130)\end{array}$ & $\begin{array}{l}-0.072 \\
(0.131)\end{array}$ & $\begin{array}{l}-0.052 \\
(0.020)\end{array}$ & $\begin{array}{l}-0.048 \\
(0.020)\end{array}$ \\
\hline Black & $\begin{array}{c}0.085 \\
(0.038)\end{array}$ & $\begin{array}{c}0.095 \\
(0.041)\end{array}$ & $\begin{array}{l}-0.192 \\
(0.092)\end{array}$ & $\begin{array}{l}-0.194 \\
(0.100)\end{array}$ & $\begin{array}{l}-0.020 \\
(0.090)\end{array}$ & $\begin{array}{c}0.014 \\
(0.092)\end{array}$ & $\begin{array}{l}-0.287 \\
(0.104)\end{array}$ & $\begin{array}{c}-0.244 \\
(0.108)\end{array}$ \\
\hline Have Kids & $\begin{array}{c}0.015 \\
(0.021)\end{array}$ & $\begin{array}{c}0.013 \\
(0.022)\end{array}$ & $\begin{array}{c}-0.089 \\
(0.042)\end{array}$ & $\begin{array}{l}-0.087 \\
(0.044)\end{array}$ & $\begin{array}{l}-0.009 \\
(0.041)\end{array}$ & $\begin{array}{l}-0.020 \\
(0.042)\end{array}$ & $\begin{array}{c}0.007 \\
(0.050)\end{array}$ & $\begin{array}{c}0.000 \\
(0.051)\end{array}$ \\
\hline Female & $\begin{array}{c}0.047 \\
(0.019)\end{array}$ & $\begin{array}{c}0.036 \\
(0.021)\end{array}$ & $\begin{array}{l}-0.091 \\
(0.043)\end{array}$ & $\begin{array}{l}-0.071 \\
(0.044)\end{array}$ & $\begin{array}{l}-0.048 \\
(0.039)\end{array}$ & $\begin{array}{l}-0.028 \\
(0.041)\end{array}$ & $\begin{array}{l}-0.158 \\
(0.045)\end{array}$ & $\begin{array}{l}-0.119 \\
(0.048)\end{array}$ \\
\hline Constant & $\begin{array}{c}0.910 \\
(0.146)\end{array}$ & $\begin{array}{c}1.087 \\
(0.147)\end{array}$ & $\begin{array}{l}-1.042 \\
(0.356)\end{array}$ & $\begin{array}{l}-1.207 \\
(0.378)\end{array}$ & $\begin{array}{l}-1.816 \\
(0.343)\end{array}$ & $\begin{array}{c}-2.072 \\
(0.053)\end{array}$ & $\begin{array}{l}-1.056 \\
(0.358)\end{array}$ & $\begin{array}{l}-1.398 \\
(0.350)\end{array}$ \\
\hline $\begin{array}{l}\text { Controls for Year Effects? } \\
\text { Controls for Industry, Occupation, }\end{array}$ & Yes & Yes & Yes & Yes & Yes & Yes & Yes & Yes \\
\hline and Parents' Education? & No & Yes & No & Yes & No & Yes & No & Yes \\
\hline $\mathrm{N}$ & 4,776 & 4,160 & 4,776 & 4,160 & 4,776 & 4,160 & 4,776 & 4,160 \\
\hline
\end{tabular}

Notes: Estimation is by random effects, including time effects for each wave of the data. Due to missing information on family background, industry and occupation, sample sizes differ between first and second columns. Tobit regressions are left-censored at zero. Standard errors are in parentheses. 
Table 5b: Tobit Regressions of Portfolio Shares - Married Couples Dependent Variable is the Share of Financial Wealth Held in a Particular Asset

\begin{tabular}{|c|c|c|c|c|c|c|c|c|}
\hline \multirow[b]{2}{*}{ Explanatory Variable } & \multicolumn{2}{|c|}{ Safe Assets } & \multicolumn{2}{|c|}{ Retirement } & \multicolumn{2}{|c|}{ Bonds } & \multicolumn{2}{|c|}{ Risky Assets } \\
\hline & $\overline{(1)}$ & (2) & $(\overline{1)}$ & (2) & (1) & (2) & (1) & $(2)$ \\
\hline \multirow[t]{2}{*}{ Husband Sick } & 0.041 & 0.041 & -0.087 & -0.079 & 0.022 & 0.004 & -0.037 & -0.023 \\
\hline & $(0.009)$ & $(0.010)$ & $(0.015)$ & $(0.016)$ & $(0.024)$ & $(0.030)$ & $(0.018)$ & $(0.019)$ \\
\hline \multirow[t]{2}{*}{ Wife Sick } & 0.037 & 0.034 & -0.039 & -0.041 & -0.048 & -0.005 & -0.076 & -0.052 \\
\hline & $(0.010)$ & $(0.011)$ & $(0.017)$ & $(0.018)$ & $(0.029)$ & $(0.040)$ & $(0.020)$ & $(0.02)$ \\
\hline \multirow[t]{2}{*}{ Husband Age } & 0.001 & 0.000 & 0.000 & 0.001 & 0.004 & 0.002 & -0.001 & -0.001 \\
\hline & $(0.001)$ & $(0.001)$ & $(0.002)$ & $(0.002)$ & $(0.002)$ & $(0.003)$ & $(0.002)$ & $(0.00$ \\
\hline \multirow[t]{2}{*}{ Wife Age } & -0.006 & -0.006 & 0.010 & 0.009 & 0.004 & 0.002 & 0.007 & 0.007 \\
\hline & $(0.001)$ & $(0.001)$ & $(0.002)$ & $(0.002)$ & $(0.002)$ & $(0.002)$ & $(0.002)$ & $(0.00$ \\
\hline \multirow[t]{2}{*}{ Husband HS } & -0.105 & -0.109 & 0.196 & 0.209 & 0.129 & 0.153 & 0.171 & 0.146 \\
\hline & $(0.014)$ & $(0.017)$ & $(0.026)$ & $(0.030)$ & $(0.036)$ & $(0.044)$ & $(0.028)$ & $(0.033)$ \\
\hline \multirow[t]{2}{*}{ Wife HS } & -0.105 & -0.094 & 0.197 & 0.182 & 0.170 & 0.173 & 0.251 & 0.247 \\
\hline & $(0.014)$ & $(0.018)$ & $(0.026)$ & $(0.031)$ & $(0.039)$ & $(0.048)$ & $(0.029)$ & $(0.03$ \\
\hline \multirow[t]{2}{*}{ Husband Some College } & -0.139 & -0.139 & 0.184 & 0.197 & 0.156 & 0.142 & 0.296 & 0.248 \\
\hline & $(0.016)$ & $(0.020)$ & $(0.031)$ & $(0.035)$ & $(0.040)$ & $(0.047)$ & $(0.032)$ & $(0.037$ \\
\hline \multirow[t]{2}{*}{ Wife Some College } & -0.146 & -0.123 & 0.282 & 0.255 & 0.165 & 0.173 & 0.282 & 0.246 \\
\hline & $(0.017)$ & $(0.020)$ & $(0.030)$ & $(0.034)$ & $(0.043)$ & $(0.052)$ & $(0.033)$ & $(0.03$ \\
\hline \multirow[t]{2}{*}{ Husband College } & -0.186 & -0.178 & 0.238 & 0.227 & 0.247 & 0.161 & 0.345 & 0.286 \\
\hline & $(0.020)$ & $(0.023)$ & $(0.036)$ & $(0.039)$ & $(0.043)$ & $(0.048)$ & $(0.037)$ & $(0.04$ \\
\hline \multirow[t]{2}{*}{ Wife College } & -0.192 & -0.170 & 0.306 & 0.276 & 0.247 & 0.223 & 0.327 & 0.278 \\
\hline & $(0.023)$ & $(0.027)$ & $(0.042)$ & $(0.046)$ & $(0.051)$ & $(0.055)$ & $(0.043)$ & $(0.04$ \\
\hline \multirow[t]{2}{*}{ Husband Post College } & -0.176 & -0.181 & 0.240 & 0.237 & 0.321 & 0.181 & 0.311 & 0.265 \\
\hline & $(0.020)$ & $(0.024)$ & $(0.038)$ & $(0.042)$ & $(0.043)$ & $(0.047)$ & $(0.037)$ & $(0.04$ \\
\hline \multirow[t]{2}{*}{ Wife Post College } & -0.182 & -0.149 & 0.336 & 0.307 & 0.216 & 0.213 & 0.286 & 0.237 \\
\hline & $(0.023)$ & $(0.027)$ & $(0.043)$ & $(0.048)$ & $(0.051)$ & $(0.056)$ & $(0.044)$ & $(0.04$ \\
\hline \multirow[t]{2}{*}{ Net Worth/(10^6) } & -0.173 & -0.167 & 0.157 & 0.137 & 0.234 & 0.083 & 0.307 & 0.298 \\
\hline & $(0.011)$ & $(0.012)$ & $(0.018)$ & $(0.019)$ & $(0.024)$ & $(0.022)$ & $(0.020)$ & $(0.02$ \\
\hline \multirow[t]{2}{*}{ Net Worth Squared/(10^12) } & 0.019 & 0.018 & -0.023 & -0.020 & -0.024 & -0.008 & -0.031 & -0.030 \\
\hline & $(0.002)$ & $(0.002)$ & $(0.003)$ & $(0.003)$ & $(0.004)$ & $(0.003)$ & $(0.003)$ & $(0.00$ \\
\hline \multirow[t]{2}{*}{$\mathrm{HH}$ Income/(10^6) } & -0.261 & -0.188 & 0.236 & 0.179 & 0.296 & 0.004 & 0.390 & 0.293 \\
\hline & $(0.086)$ & $(0.091)$ & $(0.126)$ & $(0.129)$ & $(0.162)$ & $(0.152)$ & $(0.141)$ & $(0.14$ \\
\hline \multirow[t]{2}{*}{$\mathrm{HH}$ Income Squared/(10^12) } & 0.116 & 0.083 & -0.098 & -0.080 & -0.110 & -0.017 & -0.198 & -0.141 \\
\hline & $(0.060)$ & $(0.062)$ & $(0.087)$ & $(0.087)$ & $(0.106)$ & $(0.095)$ & $(0.093)$ & $(0.09$ \\
\hline \multirow[t]{2}{*}{ Husband Black } & 0.120 & 0.113 & -0.221 & -0.197 & -0.145 & -0.015 & -0.235 & -0.208 \\
\hline & $(0.017)$ & $(0.021)$ & $(0.035)$ & $(0.042)$ & $(0.048)$ & $(0.074)$ & $(0.036)$ & $(0.04$ \\
\hline \multirow[t]{2}{*}{ Have Kids } & -0.013 & -0.031 & -0.005 & 0.003 & -0.057 & -0.004 & 0.041 & 0.091 \\
\hline & $(0.028)$ & $(0.033)$ & $(0.062)$ & $(0.068)$ & $(0.056)$ & $(0.051)$ & $(0.053)$ & $(0.06$ \\
\hline Constant & 1.136 & 1.192 & -0.978 & -0.921 & -1.543 & -2.675 & -1.139 & -1.311 \\
\hline & $(0.073)$ & $(0.080)$ & $(0.141)$ & $(0.143)$ & $(0.165)$ & $(0.151)$ & $(0.139)$ & $(0.14$ \\
\hline Controls for Year Effects? & Yes & Yes & Yes & Yes & Yes & Yes & Yes & Yes \\
\hline $\begin{array}{l}\text { Controls for Industry, Occupation, } \\
\text { and Parents' Education? }\end{array}$ & No & Yes & No & Yes & No & Yes & No & Yes \\
\hline $\mathrm{N}$ & 12,865 & 10,226 & 12,865 & 10,226 & 12,865 & 10,226 & 12,865 & \\
\hline
\end{tabular}

Notes: Estimation is by random effects. Due to missing information on family background, industry and occupation, sample sizes differ between first and second columns. Tobit regressions are left-censored at zero. Standard errors are in parentheses. 
Table 6a: Tobit Regressions of Portfolio Shares - Alternative Specifications for Singles Dependent Variable is the Share of Financial Wealth Held in a Particular Asset

\begin{tabular}{|c|c|c|c|c|}
\hline Explanatory Variable & $\underline{\text { Safe Assets }}$ & $\underline{\text { Retirement }}$ & Bonds & $\underline{\text { Risky Assets }}$ \\
\hline & \multicolumn{4}{|c|}{$\underline{\text { Risk Preferences }}$} \\
\hline Sick & $\begin{array}{c}0.155 \\
(0.049)\end{array}$ & $\begin{array}{l}-0.176 \\
(0.054)\end{array}$ & $\begin{array}{l}-0.175 \\
(0.084)\end{array}$ & $\begin{array}{l}-0.151 \\
(0.059)\end{array}$ \\
\hline \multirow[t]{2}{*}{ Risk Taker } & $\begin{array}{l}-0.071 \\
(0.042)\end{array}$ & $\begin{array}{c}0.017 \\
(0.045)\end{array}$ & $\begin{array}{l}-0.039 \\
(0.056)\end{array}$ & $\begin{array}{c}0.110 \\
(0.046)\end{array}$ \\
\hline & \multicolumn{4}{|c|}{ Planning Horizon } \\
\hline Sick & $\begin{array}{c}0.131 \\
(0.050)\end{array}$ & $\begin{array}{l}-0.151 \\
(0.054)\end{array}$ & $\begin{array}{l}-0.117 \\
(0.079)\end{array}$ & $\begin{array}{l}-0.129 \\
(0.060)\end{array}$ \\
\hline \multicolumn{5}{|l|}{ Planning Horizon } \\
\hline$\overline{\text { Next Year }}$ & $\begin{array}{c}0.017 \\
(0.073)\end{array}$ & $\begin{array}{c}0.002 \\
(0.079)\end{array}$ & $\begin{array}{c}0.155 \\
(0.107)\end{array}$ & $\begin{array}{c}-0.066 \\
(0.088)\end{array}$ \\
\hline Next Few Years & $\begin{array}{l}-0.158 \\
(0.053)\end{array}$ & $\begin{array}{c}0.145 \\
(0.057)\end{array}$ & $\begin{array}{c}0.157 \\
(0.085)\end{array}$ & $\begin{array}{c}0.088 \\
(0.062)\end{array}$ \\
\hline Next 5-10 Years & $\begin{array}{l}-0.199 \\
(0.054)\end{array}$ & $\begin{array}{c}0.183 \\
(0.058)\end{array}$ & $\begin{array}{c}0.174 \\
(0.086)\end{array}$ & $\begin{array}{c}0.171 \\
(0.063)\end{array}$ \\
\hline \multirow[t]{2}{*}{ More Than 10 Years } & $\begin{array}{l}-0.238 \\
(0.076)\end{array}$ & $\begin{array}{c}0.222 \\
(0.081)\end{array}$ & $\begin{array}{c}0.257 \\
(0.101)\end{array}$ & $\begin{array}{c}0.142 \\
(0.086)\end{array}$ \\
\hline & \multicolumn{4}{|c|}{ Bequest Motive } \\
\hline Sick & $\begin{array}{c}0.144 \\
(0.050)\end{array}$ & $\begin{array}{l}-0.159 \\
(0.055)\end{array}$ & $\begin{array}{l}-0.136 \\
(0.080)\end{array}$ & $\begin{array}{c}0.080 \\
(0.013)\end{array}$ \\
\hline \multicolumn{5}{|l|}{ Likelihood of Leaving Bequest } \\
\hline Definitely & $\begin{array}{l}-0.154 \\
(0.059)\end{array}$ & $\begin{array}{c}0.079 \\
(0.064)\end{array}$ & $\begin{array}{c}0.068 \\
(0.076)\end{array}$ & $\begin{array}{c}0.166 \\
(0.066)\end{array}$ \\
\hline Probably & $\begin{array}{l}-0.190 \\
(0.059)\end{array}$ & $\begin{array}{c}0.139 \\
(0.064)\end{array}$ & $\begin{array}{c}0.009 \\
(0.080)\end{array}$ & $\begin{array}{c}0.149 \\
(0.066)\end{array}$ \\
\hline Possibly & $\begin{array}{l}-0.083 \\
(0.058)\end{array}$ & $\begin{array}{c}0.068 \\
(0.062)\end{array}$ & $\begin{array}{c}0.143 \\
(0.072)\end{array}$ & $\begin{array}{c}0.088 \\
(0.066)\end{array}$ \\
\hline \multirow[t]{2}{*}{ Probably Not } & $\begin{array}{l}-0.141 \\
(0.050)\end{array}$ & $\begin{array}{c}0.136 \\
(0.053)\end{array}$ & $\begin{array}{l}-0.018 \\
(0.072)\end{array}$ & $\begin{array}{c}0.067 \\
(0.058)\end{array}$ \\
\hline & \multicolumn{4}{|c|}{$\underline{\text { Health Insurance }}$} \\
\hline Sick & $\begin{array}{c}0.048 \\
(0.014)\end{array}$ & $\begin{array}{l}-0.174 \\
(0.033)\end{array}$ & $\begin{array}{l}-0.089 \\
(0.050)\end{array}$ & $\begin{array}{l}-0.099 \\
(0.039)\end{array}$ \\
\hline Insured & $\begin{array}{l}-0.004 \\
(0.013)\end{array}$ & $\begin{array}{c}0.016 \\
(0.028)\end{array}$ & $\begin{array}{c}0.021 \\
(0.044)\end{array}$ & $\begin{array}{c}0.042 \\
(0.034)\end{array}$ \\
\hline
\end{tabular}

Notes: All regressions include controls for age, education, race, sex, household income, total net worth and the presence of children as in Table $5 \mathrm{a}$. The models that include health insurance information are random-effects tobits using 4 waves of data and including year effects, while all other models are crosssection regressions using wave 1 data (since these questions are not asked in other waves). Tobit regressions are left-censored at zero. Omitted category for planning horizon is "next few months". Omitted category for bequest motive is "definitely not". Standard errors are in parentheses. 
Table 6b: Tobit Regressions of Portfolio Shares - Married Couples

Dependent Variable is the Share of Financial Wealth Held in a Particular Asset

\begin{tabular}{|c|c|c|c|c|}
\hline Explanatory Variable & $\underline{\text { Safe Assets }}$ & $\underline{\text { Retirement }}$ & Bonds & Risky Assets \\
\hline & \multicolumn{4}{|c|}{$\underline{\text { Risk Preferences }}$} \\
\hline Husband Sick & $\begin{array}{c}0.115 \\
(0.027)\end{array}$ & $\begin{array}{l}-0.166 \\
(0.029)\end{array}$ & $\begin{array}{l}-0.003 \\
(0.038)\end{array}$ & $\begin{array}{l}-0.013 \\
(0.031)\end{array}$ \\
\hline Wife Sick & $\begin{array}{c}0.112 \\
(0.029)\end{array}$ & $\begin{array}{l}-0.064 \\
(0.031)\end{array}$ & $\begin{array}{l}-0.141 \\
(0.052)\end{array}$ & $\begin{array}{l}-0.113 \\
(0.034)\end{array}$ \\
\hline Husband Risk Taker & $\begin{array}{l}-0.024 \\
(0.022)\end{array}$ & $\begin{array}{l}-0.006 \\
(0.023)\end{array}$ & $\begin{array}{c}0.015 \\
(0.028)\end{array}$ & $\begin{array}{c}0.034 \\
(0.024)\end{array}$ \\
\hline \multirow[t]{2}{*}{ Wife Risk Taker } & $\begin{array}{l}-0.008 \\
(0.023)\end{array}$ & $\begin{array}{c}0.007 \\
(0.024)\end{array}$ & $\begin{array}{c}0.033 \\
(0.029)\end{array}$ & $\begin{array}{l}-0.009 \\
(0.025)\end{array}$ \\
\hline & \multicolumn{4}{|c|}{ Planning Horizon } \\
\hline Husband Sick & $\begin{array}{c}0.104 \\
(0.027)\end{array}$ & $\begin{array}{l}-0.150 \\
(0.029)\end{array}$ & $\begin{array}{l}-0.023 \\
(0.039)\end{array}$ & $\begin{array}{l}-0.003 \\
(0.031)\end{array}$ \\
\hline Wife Sick & $\begin{array}{c}0.102 \\
(0.029)\end{array}$ & $\begin{array}{l}-0.047 \\
(0.031)\end{array}$ & $\begin{array}{l}-0.120 \\
(0.051)\end{array}$ & $\begin{array}{l}-0.119 \\
(0.035)\end{array}$ \\
\hline \multicolumn{5}{|c|}{ Husband Planning Horizon } \\
\hline Next Year & $\begin{array}{c}-0.030 \\
(0.041)\end{array}$ & $\begin{array}{c}0.060 \\
(0.043)\end{array}$ & $\begin{array}{c}0.010 \\
(0.056)\end{array}$ & $\begin{array}{c}0.001 \\
(0.046)\end{array}$ \\
\hline Next Few Years & $\begin{array}{l}-0.077 \\
(0.031)\end{array}$ & $\begin{array}{c}0.078 \\
(0.033)\end{array}$ & $\begin{array}{c}0.003 \\
(0.044)\end{array}$ & $\begin{array}{c}0.048 \\
(0.036)\end{array}$ \\
\hline Next 5-10 Years & $\begin{array}{l}-0.078 \\
(0.032)\end{array}$ & $\begin{array}{c}0.097 \\
(0.034)\end{array}$ & $\begin{array}{c}0.046 \\
(0.044)\end{array}$ & $\begin{array}{c}0.056 \\
(0.036)\end{array}$ \\
\hline More Than 10 Years & $\begin{array}{l}-0.099 \\
(0.041)\end{array}$ & $\begin{array}{c}0.097 \\
(0.043)\end{array}$ & $\begin{array}{c}0.087 \\
(0.051)\end{array}$ & $\begin{array}{c}0.108 \\
(0.045)\end{array}$ \\
\hline \multicolumn{5}{|l|}{ Wife Planning Horizon } \\
\hline Next Year & $\begin{array}{c}0.049 \\
(0.039)\end{array}$ & $\begin{array}{c}-0.022 \\
(0.041)\end{array}$ & $\begin{array}{l}-0.028 \\
(0.055)\end{array}$ & $\begin{array}{l}-0.038 \\
(0.044)\end{array}$ \\
\hline Next Few Years & $\begin{array}{l}-0.017 \\
(0.030)\end{array}$ & $\begin{array}{c}0.046 \\
(0.032)\end{array}$ & $\begin{array}{c}0.023 \\
(0.041)\end{array}$ & $\begin{array}{l}-0.040 \\
(0.033)\end{array}$ \\
\hline Next 5-10 Years & $\begin{array}{l}-0.061 \\
(0.031)\end{array}$ & $\begin{array}{c}0.087 \\
(0.033)\end{array}$ & $\begin{array}{c}0.018 \\
(0.042)\end{array}$ & $\begin{array}{l}-0.004 \\
(0.034)\end{array}$ \\
\hline \multirow[t]{2}{*}{ More Than 10 Years } & $\begin{array}{l}-0.034 \\
(0.040)\end{array}$ & $\begin{array}{c}0.047 \\
(0.042)\end{array}$ & $\begin{array}{c}0.032 \\
(0.050)\end{array}$ & $\begin{array}{c}0.030 \\
(0.044)\end{array}$ \\
\hline & \multicolumn{4}{|c|}{ Bequest Motive } \\
\hline Husband Sick & $\begin{array}{c}0.122 \\
(0.025)\end{array}$ & $\begin{array}{l}-0.158 \\
(0.027)\end{array}$ & $\begin{array}{l}-0.016 \\
(0.035)\end{array}$ & $\begin{array}{l}-0.020 \\
(0.029)\end{array}$ \\
\hline Wife Sick & $\begin{array}{c}0.118 \\
(0.027)\end{array}$ & $\begin{array}{l}-0.077 \\
(0.029)\end{array}$ & $\begin{array}{l}-0.121 \\
(0.046)\end{array}$ & $\begin{array}{l}-0.113 \\
(0.033)\end{array}$ \\
\hline \multicolumn{5}{|c|}{ Likelihood of Leaving Bequest } \\
\hline Definitely & $\begin{array}{l}-0.027 \\
(0.031)\end{array}$ & $\begin{array}{l}-0.016 \\
(0.033)\end{array}$ & $\begin{array}{c}0.069 \\
(0.038)\end{array}$ & $\begin{array}{c}0.096 \\
(0.035)\end{array}$ \\
\hline Probably & $\begin{array}{l}-0.073 \\
(0.028)\end{array}$ & $\begin{array}{c}0.053 \\
(0.029)\end{array}$ & $\begin{array}{c}0.025 \\
(0.036)\end{array}$ & $\begin{array}{c}0.090 \\
(0.032)\end{array}$ \\
\hline Possibly & $\begin{array}{l}-0.064 \\
(0.029)\end{array}$ & $\begin{array}{c}0.030 \\
(0.030)\end{array}$ & $\begin{array}{c}0.053 \\
(0.037)\end{array}$ & $\begin{array}{c}0.102 \\
(0.033)\end{array}$ \\
\hline Probably Not & $\begin{array}{l}-0.036 \\
(0.025)\end{array}$ & $\begin{array}{c}0.031 \\
(0.027)\end{array}$ & $\begin{array}{l}-0.019 \\
(0.035)\end{array}$ & $\begin{array}{c}0.049 \\
(0.029)\end{array}$ \\
\hline
\end{tabular}


Table 6b (continued): Tobit Regressions of Portfolio Shares - Married Couples

Dependent Variable is the Share of Financial Wealth Held in a Particular Asset

\begin{tabular}{|c|c|c|c|c|}
\hline Explanatory Variable & Safe Assets & Retirement & Bonds & Risky Assets \\
\hline & \multicolumn{4}{|c|}{ Health Insurance } \\
\hline Husband Sick & $\begin{array}{c}0.042 \\
(0.009)\end{array}$ & $\begin{array}{c}-0.088 \\
(0.015)\end{array}$ & $\begin{array}{c}0.022 \\
(0.024)\end{array}$ & $\begin{array}{c}-0.038 \\
(0.018)\end{array}$ \\
\hline Wife Sick & $\begin{array}{c}0.037 \\
(0.010)\end{array}$ & $\begin{array}{c}-0.040 \\
(0.017)\end{array}$ & $\begin{array}{c}-0.048 \\
(0.029)\end{array}$ & $\begin{array}{c}-0.076 \\
(0.020)\end{array}$ \\
\hline Couple Insured & $\begin{array}{l}-0.025 \\
(0.010)\end{array}$ & $\begin{array}{c}0.060 \\
(0.018)\end{array}$ & $\begin{array}{c}-0.016 \\
(0.028)\end{array}$ & $\begin{array}{c}0.042 \\
(0.021)\end{array}$ \\
\hline
\end{tabular}

Notes: All regressions include controls for age, education, race, sex, household income, total net worth and the presence of children as in Table $4 \mathrm{~b}$. The models that include health insurance information are randomeffects tobits using 4 waves of data, while all other models are cross-section regressions using wave 1 data (since these questions are not asked in other waves). Tobit regressions are left-censored at zero. Omitted category for planning horizon is "a few months". Omitted category for bequest motive is "definitely not". Standard errors are in parentheses. 